\title{
Social Campaign Message about Energy Saving in Indonesia in YouTube
}

\author{
Yanuar Luqman \\ \{yanuar.luqman@live.undip.ac.id\} \\ Universitas Diponegoro, Indonesia
}

\begin{abstract}
This study describes the contents of energy-saving campaigns on social media platforms, especially YouTube. The background of this study is that energy conservation is one of the solutions in overcoming the problem of limited energy in addition to developing new and renewable energy. Community participation, especially millennials, is needed to overcome energy problems in Indonesia. With new media, the public can become objects and become subjects in energy-saving campaigns. In this study, the YouTube platform was chosen as a medium that can be used for energy-saving campaigns. YouTube that presents audiovisual information and allows for more open social interaction. Theories in this study are Social Cognitive Theory, ComputerMediated Communication, and Social Marketing. This study uses a qualitative descriptive approach. The conclusion of this research is the narration campaign of energy-saving tends to save electricity. Found out that the viewer and subscriber are not much. Animation has become the choice of this energy-saving campaign in this research. The top-down social marketing approach for instrument changes has similarities with modernization, and the theory of innovation diffusion does not fit into the concept of mass self-communication.
\end{abstract}

Keywords: Energy, Campaign, Social Media, YouTube.

\section{Introduction}

Energy-saving is one of the solutions in overcoming energy problems besides developing new and renewable energy. Community participation is needed to overcome the energy problem in Indonesia. Communication through the energy-saving campaign is one of the efforts to increase community participation. The community needs to know, aware and participate in energy-saving movement because of the background of the rapid growth of energy consumption amid the decline in the amount of fossil energy reserves which are still the main source of electricity in Indonesia. The purpose of this energy movement is to help the government in realizing equitable energy that is in line with the paradigm of global energy management.

Energy-saving socialization and education ever undertaken by government are the distribution of energy-saving lamp, and 10 Percent Cut Movement in 2017 involving the Ministry of Energy and Mineral Resources, local governments, universities, mass media, nongovernmental organizations (NGOs), bloggers, netizens, bicycle communities, energy-saving and environmental communities, hobby communities, commercial building associations, hotels and the general public. The purpose of the government public campaign raising public awareness of the importance of saving energy. 
In addition to being the object of an energy-saving campaign, the community can also play an active role as the subject of the campaign. Community participation needed to achieve energy-saving goals with socio-economic, energy and environmental indicators. The presence of new media enables the wider community to participate in all matters with a variety of media platforms. With new media, the community can be both object and subject in the energy-saving campaign. The new media includes social media using website-based technology or applications that can transform communication into an interactive dialog. The examples of social media that are widely used are YouTube, Facebook, Blogs, Twitter, and others.

Online networks form the result of Wang and Taylor's research [1] showed that Twitter's online network platform can promote energy-saving information. Regarding diffusion practice based on research findings Mohammadi et al [2] showed that the diffusion message network that supports energy-saving practices is largely managed by the activities of a dedicated organization but their effort did not produce substantial public awareness, because most of the communication trapped effectively within the organization where the message was only shared between organizations.

The use of social media in energy-saving campaigns is the right choice in the current era of information technology. This study chooses the YouTube platform as a media that can be used for the energy-saving campaign. YouTube is a social media platform that presents audiovisual information and allows for more open social interaction. These are the data that show the potential of using social media for the importance of energy-saving campaigns. Statista data cited by katadata.co.id, users of social media in Indonesia in 2017 reached 96 million users. In 2022 it is estimated to increase 30 percent [3]. Wear social Hootsuite research results cited by katadata.co.id released in January 2019, mobile social media users (gadgets) reached 130 million or about $48 \%$ of the population [4]. Wear Social Survey cited by katadata.co.id mentions that the Indonesian population who actively plays social media reaches 150 million people. Of the various types of social media, YouTube is the most widely played. In addition to YouTube, the social media that are widely used by Indonesian people are WhatsApp, Facebook, and Instagram [5]. The following screenshots from the video about the energy saving campaign.

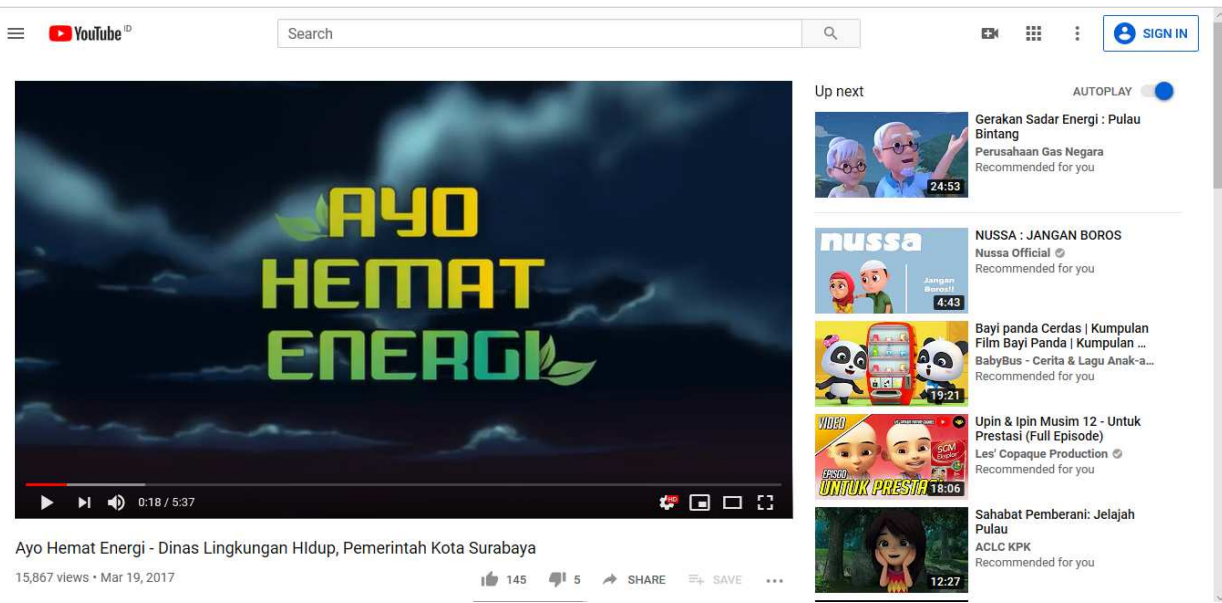

Source: https://www.youtube.com/watch?v=uewAJAT8Yrk\&t=5s 


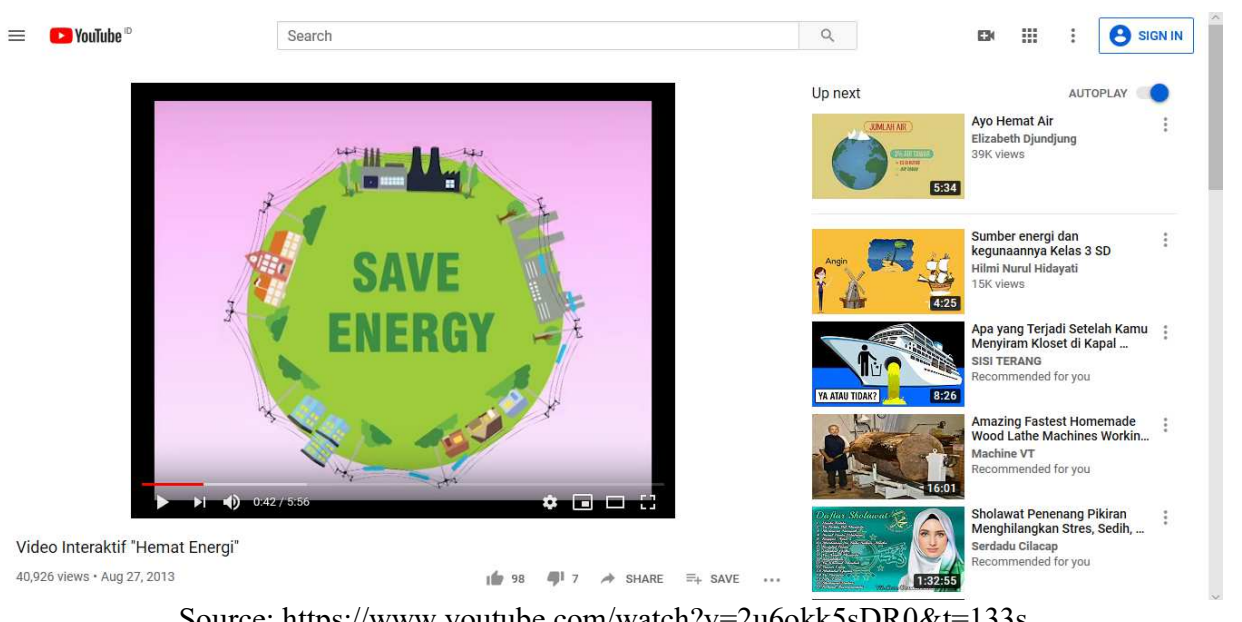

Source: https://www.youtube.com/watch?v=2u6okk5sDR0\&t=133s

Research on energy saving campaigns is related to environmental communication. Emily Plec uses the phrase inter-natural communication; which communication affects the perception of the natural world and how to define and act on relationships with nature. Human discourse about nature reflects, develops, produces, and naturalizes human attitudes and practices towards the environment [6]. The campaign uses communication strategies and theories to influence a wide audience in a measurable way. Kami J. Silk said that the campaign was very complex because it is an art and also a science. Creative ideas are needed to attract and hold attention, but also the fundamental knowledge of communication theory to maximize the understanding of the audience, message content, and evaluation strategy. A clear understanding of the campaign process will increase the possibility of obtaining a successful campaign result [7].

Social Cognitive Theory (SCT) Albert Bandura in Littlejohn dan Foss [6] become a foothold in this research assuming that this theory entered the realm of message design. The main idea of SCT is that people learn from observation, reinforcement or punishment affecting their behavior and the hope of subsequent results in the same situation. SCT is important for message design campaign because it explains the idea that people learn and are influenced when they make observations, which includes observing campaign messages. SCT provides guidelines on observational learning that can be translated directly into message design strategies for campaigns.

The emergence of the Internet which later developed social media and ComputerMediated Communication (CMC) has created additional forms of reality. That reality is "new media". Social media approach differentiates the media in how close they are with the model of face-to-face interaction. New media are more interactive and create a new personal communication feeling. New media has weaknesses, according to Bromme et al, potential weaknesses include different meanings between actors, the structure of interaction, learning process through internet intermediaries also need social structure to ensure the continuity of the process of information dissemination [8]. Thurlow et al, added that absenteeism is a weakness of $\mathrm{CMC}$ which triggers low social presence. Low social presence triggers high orientation towards the goal but less attention to the quality of the relationship [9]. 
The new concept of communication emerged with the advent of the internet new form of communication, mass self-communication. This is mass communication because it has the potential to reach a global audience, such as posting videos on YouTube, blogs with RSS links to a number of web sources. At the same time, it is self-communication because the production of messages is self-generated, definitions of potential recipients are directed themselves, and the retrieval of messages or certain content from electronic communication networks is self-selected. Three forms of communication (interpersonal, mass communication, and mass self-communication) together, interact, and complement each other rather than replacing each other [10].

Social marketing is a response to the need to be "socially relevant" and "socially responsible". In the family tree of development communication written by Waisbord, social marketing does not come out of diffusion or participatory theory. The focus of social marketing is in the behavioral changing, understanding communication as a persuasion (information transmission), and the top-down approach to instrument change has similarities with the modernization and innovation diffusion theory. Social marketing use practice standard technique in commercial marketing to promote pro-social behavior [11].

Unlike traditional marketing management, social marketing does not aim to select the best segments of the market and develop a strong position in it. Social marketing needs to penetrate in all segments. Coordinated social marketing is needed to increase its benefits and reduce perceived obstacles. Social marketing is a prerequisite for the first stage (introduction) in the product life cycle. Commercial marketing can assume a role in the stages of growth and maturity [12]. It is hope with communicating the information about energy-saving efforts, the community will understand and actively participate.

In energy-saving campaigns, content becomes an important factor, before communicating to the community, it is necessary to discuss the messages made and designed for the wider community. What is the energy-saving campaign content created on YouTube's social media platform? This can be seen by describing the contents of the energy-saving campaign content on the YouTube social media platform.

\section{Research Method}

This study uses a qualitative descriptive approach. According to Creswell's qualitative research as a research approach that starts with assumptions, the lens of interpretation/theoretical, and studies of research problems that examine how individuals or groups interpret social or humanitarian problems. Data is collected in the natural environment while maintaining sensitivity to the subject under study and analyzed to form patterns or themes [13]. This research was conducted by describing the energy-saving campaign content.

This research focuses on the energy-saving campaign content that aired on YouTube in the past year. Primary data is obtained from the energy-saving campaign contents that aired on YouTube in the past year and information from the makers. Secondary data were obtained from literature studies and other indirect sources. Following are the key sentences used for energy-saving campaigns:

a) Hemat listrik-hemat banyak energi (Save electricity-save a lot of energy)

b) Sadar energi-Jangan lupa cabut kabel TV-nya (Conscious of energy-don't forget to unplug the television cable) 
c) Semakin banyak yang menghemat energi, maka bumi akan semakin terjaga karena sumber daya alam tidak cepat habis (The more that saves energy, the earth will be more maintained because the natural resource does not run out quickly)

d) Hemat sekarang, kaya dimasa depan (Save now, be rich in the future)

e) Hemat listrik-hemat biaya, bumi terjaga, Indonesia bahagia (Save electricity-save money, the earth is maintained, Indonesia is happy)

f) Ayo hemat energi untuk kehidupan yang lebih baik (Let's save energy for a better life)

g) MOTTAINAI (Mottainai is a Japanese concept combining a sense of respect for various resources or objects (e.g. natural resources, products, time, money, etc.) with a sense of regret or guilt we feel when they are used wastefully)).

These videos were chosen based on energy-saving keywords, then selected based on the highest ranking of people watching. Before being determined as a sample, the videos were selected to avoid video duplication. The videos are accessed in September-October 2019.

\section{Result and Discussion}

Data on energy-saving campaigns is obtained by searching on the YouTube platform. In the search section, the keywords used are "energy saving and energy saving campaigns". Most of the videos obtained are videos that contain electricity energy-saving campaigns. If examined further, some of the videos uploaded to the YouTube platform turned out to be reuploaded videos. The video format that gets many viewers is animation. Video viewers on YouTube are not many, of the 50 videos that were collected the highest at 98 thousand and the lowest was 8 with an average of 8867 viewers.

The narrative of energy-saving campaigns tends to focus more on electricity saving efforts. The definition of energy based on the President Regulation Number 5/2006 about National Energy Policy is the ability to do work which can be in the form of heat, light, mechanics, chemistry, and electromagnetics. The energy source is something that can produce energy, both directly and through a process of conversion or transformation. Energy resources are natural resources that can be utilized, both as energy sources and as energy. Energy is in the form of electricity and or energy produced from fuels for transportation.

National energy consumption reached 1.23 Billion Barrels of Oil Equivalent (BOE) in 2017. Based on data from the Ministry of Energy and Mineral Resources cited by katadata.co.id [14], of that number 382.95 million BOE or nearly one-third of energy consumption for the household sector and is the largest compared to other sectors. In the second place, the energy consumption is for the transportation sector, which reached 361.7 million BOE $(29.31 \%)$ then followed by the industrial sector which amounted to 273.86 million BOE (22.19\%). From these data, it is natural that energy-saving campaigns tend to be on the narrative of saving electricity for the household sector.

Emily Plec stated that how to communicate affects the perception of the natural world and how to define and act on relations with nature [6]. In this study, through energy-saving campaigns, the community is expected to have a perception of the importance of behaving frugally. The community is expected to understand the reason why we have to save energy because it is related to nature conservation. Nature conservation is important because it is related to the sustainability of human life on earth. Energy-saving narratives reflect, build, produce, and naturalize people's attitudes and practices towards the environment. Energysaving campaigns through the YouTube platform are expected to use communication 
strategies and theories to influence a wide community in a measurable way. This study found that the number of viewers is not much. Communication measurements made on the YouTube platform can be seen from the number of viewers and subscribers. The theme of energy-saving does not seem to be the choice of stakeholders. Ministry of Energy and Mineral Resources (MEMR) when viewed from its official page, it seems that it did not choose YouTube as a media for any social campaigns including energy-saving campaigns. The superiority of the YouTube platform is that information is in the form of audio and visual so messages can be delivered more comprehensively and that a clearer understanding of the campaign process will increase the likelihood of obtaining successful campaign results. The success of energy-saving campaigns according to Silk [7] requires interesting content to maintain attention and understanding of the audiences.

The energy-saving campaign message design in this study uses a lot of animation formats. SCT [6], which is the basis of this research, assumes that this theory enters the realm of message design. With animation, the target audience can learn from observations, reinforcement or negative consequences affecting energy consumption behavior that is not friendly. SCT is important for the design of energy-saving campaign messages because it explains the idea of the targeted audience learns and is influenced when making observations, which includes observing energy-saving campaign messages. Animation design will likely become the guidelines of observational learning that are more detailed and can be translated into a message design strategy for energy-saving campaigns.

YouTube is a new media platform. In this study, the energy-saving campaign is using new media. The advantage of using a new media is more interactive and create a new personal communication feeling. On the other side, a new media user in this campaign has a weakness, in giving different meanings between targeted audiences and interaction structure. The learning process about the importance of saving energy through internet intermediaries needs a social structure. The social structure needed to make sure the continuity of the process of disseminating information regarding the use of energy wisely. The other weakness of using a new media is the absence trigger a low social presence. The low viewer and subscriber should be suspected because of the low social presence. The targeted audience has not been touched to be able to participate in the energy-saving campaign movement.

The amplification of the energy-saving campaign is expected to be seen from several accounts that re-post. Re-posting content makes the benefits of new media useless. A new concept of mass self-communication is in the form of mass communication because it potentially reaches a global audience, for example, video posting on YouTube. At the same time, it is a self-communication because the production of a message campaign is selfproduce, the definition of a potential recipient is directed by himself, and retrieval of messages or certain content from the electronic communication network is self-selected. The advantage of YouTube in its mass self-communication actually could be used to amplify good energysaving campaigns. The campaign message can be self-produced with YouTuber's own perspective, and designed according to the intended target audience of YouTuber.

The energy-saving campaigns included in the social marketing concept that uses a standard technique practice in commercial marketing to promote pro-social behavior (saving energy). Social marketing in the context of the energy-saving campaign is a response to the need to be "socially relevant" and "socially responsible". The social marketing approach in an energy-saving campaign focuses on behavioral changes, understanding communication as persuasion. The top-down social marketing approach for instrument changes has similarities with the modernization and diffusion innovation theory is not match with the mass selfcommunication concept. 


\section{Conclusion}

a) The narrative of energy-saving campaigns tends to focus more on electricity saving efforts. Electricity is the focus because it consumes more energy than energy in the transportation and industrial sectors.

b) This study found that the number of viewers and subscribers is not much. Measurements of communication made on the YouTube platform can be seen from the number of viewers and subscribers.

c) The energy-saving theme does not seem to be the choice of stakeholders. The Ministry of Energy and Mineral Resources (MERS), viewed from its official page, does not seem to choose YouTube as a social media campaign of any kind including energy-saving campaigns.

d) The energy-saving campaign message design in this study uses a lot of animation formats. Animation design will likely become the guidelines of observational learning that are more detailed and can be translated into a message design strategy for energysaving campaigns.

e) The top-down social marketing approach for instrument changes has similarities with the modernization and diffusion innovation theory is not match with the mass selfcommunication concept.

\section{References}

[1] Q. Wang and J. E. Taylor, "Energy saving practice diffusion in online networks," Energy Build., vol. 76, pp. 622-630, 2014.

[2] N. Mohammadi, Q. Wang, and J. E. Taylor, "Diffusion dynamics of energy saving practices in large heterogeneous online networks," PLoS One, vol. 11, no. 10, 2016.

[3] Databoks, "Pengguna Media Sosial Indonesia Mencapai 125 Juta," August 22, 2017. .

[4] Databoks, "Berapa Pengguna Media Sosial Indonesia?," February 8, 2019. [Online]. Available: https://databoks.katadata.co.id/datapublish/2019/02/08/berapa-pengguna-media-sosialindonesia. [Accessed: 08-Mar-2019].

[5] Katadata, "Youtube Medsos No. 1 di Indonesia," Maret 6, 2019. [Online]. Available: https://katadata.co.id/infografik/2019/03/06/youtube-medsos-no-1-di-indonesia. [Accessed: 08Mar-2019].

[6] J. G. Littlejohn, S. W.; Foss, K. A.; Oetzel, Theories of Human Communication. Long Grove: Waveland Press, 2017.

[7] S. W. Littlejohn and K. A. Foss, Encyclopedia of communication theory, vol. 1. Sage, 2009.

[8] R. Bromme, R. Jucks, and A. Runde, "Barriers and biases in computer-mediated expertlayperson-communication," in Barriers and biases in computer-mediated knowledge communication, Springer, 2005, pp. 89-118.

[9] C. Thurlow, L. Lengel, and A. Tomic, Computer mediated communication. Sage, 2004.

[10] M. Castells, Communication Power. Oxford: Oxford University Press, 2009.

[11] S. Waisbord, "Family Tree of Theories, Methodologies and Strategies in Development Communication, The Rockefeller Foundation," 2015. [Online]. Available: www.communicationforsocialchange.org/pdf/familytree.pdf. [Accessed: 08-Mar-2019].

[12] A. N. Menegaki, "A social marketing mix for renewable energy in Europe based on consumer stated preference surveys," Renewable Energy, vol. 39, no. 1. pp. 30-39, 2012.

[13] C. John W., Qualitative Inquiry and Research Design: Choosing Among the Five Approaches. 2013.

[14] Databoks, "Hampir Sepertiga Energi Nasional untuk Rumah Tangga," October 12, 2018. 
[Online]. Available: https://databoks.katadata.co.id/datapublish/2018/10/12/hampir-sepertigaenergi-nasional-untuk-rumah-tangga. [Accessed: 16-Oct-2019]. 